\title{
SAM Domain and HD Domain-Containing Protein 1
}

National Cancer Institute

\section{Source}

National Cancer Institute. SAM Domain and HD Domain-Containing Protein 1. NCI

Thesaurus. Code C98205.

SAM domain and HD domain-containing protein 1 (626 aa, $72 \mathrm{kDa}$ ) is encoded by the human SAMHD1 gene. This protein is involved in the regulation of the viral defense response. 